\title{
Potential of Cooperation of the EAEU Countries in the Perspective of Digitalization of the Agri-Food Sector
}

\author{
BORIS A. KHEYFETS \\ Institute of Economics of the Russian Academy of Sciences \\ 32 Nakhimovsky Prospect, Moscow, 117218; \\ Financial University under the Government of the Russian Federation \\ 49 Leningradsky Prospect, Moscow, 125993 \\ RUSSIAN FEDERATION \\ VERONIKA YU. CHERNOVA \\ Department of Marketing, \\ Peoples' Friendship University of Russia \\ 6 Miklukho-Maklaya Str., Moscow, 117198; \\ Institute of Marketing, \\ State University of Management. \\ 99, Ryazanskiy prospect st., Moscow, 109542 \\ RUSSIAN FEDERATION
}

\begin{abstract}
The paper assesses the potential of cooperation between Russia and the countries participating in the EAEU in the agri-food sector. It is revealed that the share of agricultural organizations and food industry enterprises participating in joint projects to carry out research and development is much lower than in other industries. The weak interest of Russian enterprises in innovation activity has been noted. At the same time, in the agri-food sector, certain changes have emerged in the area of intensification of innovation activity. To this end, the study assessed the potential for cooperation in innovation in the agri-food sector. The reasons for the low rate of the digital transformation of the agri-food sector and the factors involved in these processes have been analyzed.
\end{abstract}

Key-Words:- agri-food sector, cooperation, innovative development, digital inequality, digitalization.

Received: June 30, 2019. Revised: January 2, 2020. Accepted: January 4, 2020.

Published: January 13, 2020.

\section{Introduction}

At the current stage of development of the Russian agri-food sector, the problems of accelerating scientific and technical progress are becoming increasingly important. The introduction of digital technology opens up opportunities to overcome a significant lag in the industry [1]. At the same time, no country in the world can take a leading position on an international scale without cooperation with partners from other countries [2]. Currently, the issues of cooperation in the direction of innovation development, development of new technologies and digital transformation of the agrifood sector are increasingly being put on the agenda in cooperation of the EAEU member states [3].

Therefore, the purpose of this paper was to assess the potential of cooperation of the EAEU countries in the field of digitization of the agri-food sector, the analysis of the existing level of cooperation in technology exchange and the readiness of the agri-food sector for digital transformation. Main objectives of the research included an analysis of the trade potential and innovation-based cooperation between Russia and the EAEU countries and assessment whether the agri-food sector was ready for the digital transformation.

\section{Literature Review}

Issues of the development and implementation of innovative technologies in the agri-food sector are reflected in many papers (Lazko et al. [4]; Radwan [5]; Skvortsov et al. [6]; Harold et al. [7], TongKe $[8])$.

Lazko et al. emphasize the importance of innovation and investment parameters of economic growth. Platonova points out that one of the branches of the Russian economy, which does not yet have significant achievements in innovation, is agriculture. The use of digital economy in the organization of agricultural production gives a chance to domestic agricultural producers to overcome a si gnificant lag in the level of labor 
productivity compared with foreign competitors, to improve the quality and competitiveness of products.

In this connection, research on the problems of growth in labor productivity is becoming especially important. The paper by Lavrovsky et al. showed that economic growth occurs due not only to the volume of investments but also the characteristics of their quality, the impact of the innovation factor [9]. Lavrovsky offered an approach to assessing the intensity of innovation implementation based on the ratio of investment efforts and the dynamics of labor productivity. The decomposition of the increase in labor productivity into its extensive and intensive growth factors allowed the author to quantify the role of innovation and investment in breakthrough technologies in economic growth. The paper by Spasskaya and Kireev is devoted to the economic evaluation and identification of the interrelations between labor productivity and specific investments [10]. The paper by Baev and Solovyova analyzed the relationship between innovation and investment activity and proposed a comprehensive index [11].

The development of cooperation in agriculture and food industry in the Eurasian region is of great importance for ensuring the growth of labor productivity based on the introduction of breakthrough technologies (see Fomina et al. [12]; Karlik et al. [3], Shumov [13]). New digital technologies allow organizing wider and deeper cooperation ties, and the development of cooperation [14] will help strengthen the economies of the EAEU member countries and increase their competitiveness in the global market for goods and services.

The role of digital technologies in the agri-food sector is discussed in a paper by Kovács and Husti [15]. A review of literature makes it possible to specify the factors that motivate companies to develop cooperative ties, such as: accelerating technological progress and the pace of digitalization development; increasing complexity of the technological base, which requires increasing competence and additional knowledge in the related technological fields; increasing cost of development and innovation [16].

\section{Materials and Methods}

The potential of cooperation in the production sphere can be defined as the share of mutual FDI of countries in the total volume of FDI between the country and all countries of the world. The potential of cooperation in the production sphere between the two countries is the higher, the greater the share of mutual FDI. For building capacity in the manufacturing sector, it is important that the volume of mutual direct investments grows at a steady pace. For that, the authors included the average annual growth rate of FDI and the standard deviation of the FDI growth rate in the formula:

$P C_{P i}=\frac{I_{i} \cdot R P_{I i}}{\sigma_{R P I i}}: \frac{I_{W} \cdot R P_{I W}}{\sigma_{R P I W}}$,

where $I_{i}$ - the total amount of foreign direct investment of Russia and the $i$-th country in the previous year, USD million; $R P_{I i}-$ the average growth rate of the total amount of FDI of Russia and the $i$-th country over the studied period; $\sigma_{R P I i}-$ standard deviation of the FDI growth rates; $I_{w}$ - the total amount of FDI of Russia and world's countries in the previous year, USD million; $R P_{I w}-$ the average annual growth rate of the FDI of Russia and world's countries over the studied period; $\sigma_{R P I w}-$ standard deviation of the FDI growth rates.

The potential of cooperation development in trade $\left(P C_{T i}\right)$ was calculated in a similar way using the formula:

$$
P C_{T i}=\frac{T_{i} \cdot R P_{T i}}{\sigma_{R P T i}}: \frac{T_{W} \cdot R P_{T W}}{\sigma_{R P T W}},
$$

where $T_{i}$ - the total amount of mutual trade of Russia and the $i$-th country in the previous year, USD million; $R P_{T i}-$ the average annual growth rate of the total amount of mutual trade of Russia and the $i$-th country over the studied period; $\sigma_{R P T i}-$ standard deviation of the mutual trade growth rates; $T_{w}-$ the total amount of mutual trade of Russia and world's countries in the previous year, USD million; $R P_{T_{w}}-$ the average annual growth rate of the total amount of mutual trade of Russia and world's countries over the studied period; $\sigma_{R P T w}-$ standard deviation of the mutual trade growth rates.

Evaluation of innovation activity in the agri-food sector in the EAEU countries was carried out on the basis of an indicator of the intensity of innovation activity in terms of the growth of investment in fixed assets $\left(E_{F A}\right)$ :

$I_{\text {IAK }}=\frac{\Delta_{L P}}{K_{i}}$,

where $K_{i}$ - specific investments in fixed assets in the $i$-th period (calculated per person employed in agriculture); $\Delta_{L P}$ - growth in labor productivity.

Evaluation of the reduction of digital inequality between urban and rural areas in connection with the Internet access in the EAEU countries was 
carried out on the basis of the indicator of reduction of digital inequality, determined by the formula:

$I_{\text {Int }}=1-\frac{A_{\text {Int }}^{R}}{A_{\text {Int }}^{U}}$

where $I_{\text {Int }}$ - the indicator of reducing digital inequality in terms of ICT use by rural residents compared to urban residents; $A_{\text {Int }}^{R}-$ quantitative assessment of rural households with access to the Internet, the percentage of the total number of households in the rural area; $A_{\text {Int }}^{U}-$ quantitative assessment of urban households with access to the Internet, the percentage of the total number of households in the urban area.

The empirical base of the research was the official statistics of Russia, the Republic of Belarus, the Republic of Kazakhstan, as well as the empirical information of the Institute for Statistical Studies and Economics of Knowledge of the National Research University Higher School of Economics (Moscow, Russia).

\section{Results}

In the implementation of innovation activities, Russian enterprises quite often resort to various forms of technology acquisition abroad. Thus, in 2017, 35.7\% of enterprises acquired technology outside Russia, while the outflow of knowledge in the form of technology transfer was observed in $13.7 \%$ of manufacturing enterprises. In the food industry, in the implementation of technological innovations, about $40 \%$ of enterprises acquire new technologies in foreign countries, mainly in non-CIS countries (more than $88 \%$ of enterprises). The main form of technology acquisition by enterprises of the agri-food sector of the economy is the purchase of equipment. More than $50 \%$ of agricultural organizations and more than $84 \%$ of food industry enterprises use this form of technology acquisition [17]. This distribution seems to be due to the overall technological and innovative level of specific sectors; the intensity of modernization processes occurring in them; the dominance of certain types of innovative behavior; the scientific potential, etc. [14].

The share of agricultural organizations and food industry enterprises participating in joint research and development projects is noticeably lower than in other industries. Thus, about $30 \%$ of enterprises engaged in innovation and only $8.6 \%$ of food industry enterprises and $7.2 \%$ of agricultural organizations participate in joint research and development in the manufacturing industry. At the same time, the preferred type of cooperation ties in agriculture is cooperation within a project (Fig. 1).

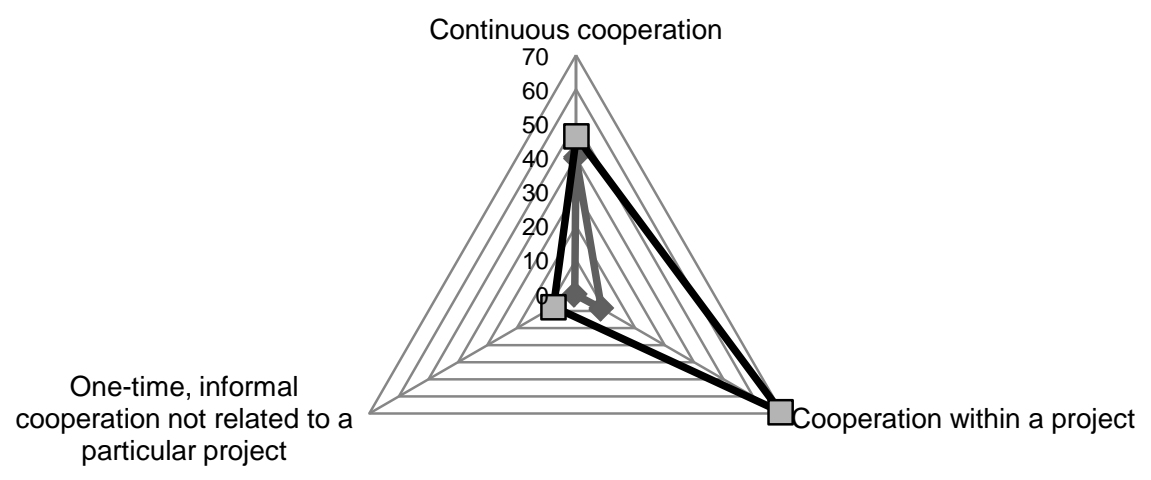

$\longrightarrow$ Food production, including beverages $\rightarrow$ Agriculture

Fig. 1. Types of cooperation ties in R\&D in the agri-food sector Source: [17]

At the same time, the development of production cooperative ties with the countries of the EAEU remains insignificant. In 2016, in partnership with the countries of the EAEU, 1 pr oject was implemented in the food industry and 3 projects in agriculture, while in the processing industry there were 124 such projects.

At present, the development of integration between Russia and its partners in the EAEU is developing in the direction of creating cooperative ties mainly in the trade sphere (Table 1). Currently, 
cooperation and its development (between Russia and Belarus/Kazakhstan) has the highest potential, as for Belarus, it is mainly in trade $(10.3 \%)$, as for Kazakhstan, it is both in trade $(5.1 \%)$, and the manufacturing sector $(5.89 \%)$.

Table 1. Potential of cooperation in the production sphere between Russia and Armenia, Belarus, Kazakhstan, Kyrgyzstan

\begin{tabular}{|l|c|c|}
\hline \multirow{2}{*}{\multicolumn{1}{c|}{ Countries }} & \multicolumn{2}{|c|}{ Cooperation potential, \% } \\
\cline { 2 - 3 } & in trade & in manufacturing \\
\hline Armenia & 0.76 & 0.05 \\
\hline Belarus & 10.30 & 0.72 \\
\hline Kazakhstan & 5.10 & 5.89 \\
\hline Kyrgyzstan & 0.47 & 0.28 \\
\hline
\end{tabular}

Source: calculated by the authors according to statistics of the Interstate Statistical Committee of the Commonwealth of Independent States [18]

Although Russia plays a key role for all of the other EAEU countries as a main supplier of goods (65.3\% of exported supplies in mutual trade) or the largest market $(31.2 \%$ of the EAEU imported supplies), there have been recently more and more trade flows from the EAEU countries to the third countries and the decreased intensity of national trade. In 2018, the EAEU external exports were 8 times over the volume of mutual exports (as of the end of 2017, the external exports were 7.1 times over), foreign imports were 4.4 times over the volume of mutual imports (in 2017, 4.65 times) [18]. The value of national trade with the EAEU countries was lower even in Belarus, exports of which following the introduced embargo on supplies of agri-foods were almost entirely redirected to
Russia [20]. Russia accounts for about $75 \%$ in the agricultural production and about $84.86 \%$ in food industry production. In agricultural production of the EAEU, in 2018, Kazakhstan and Belarus shares amounted to $11.75 \%$ and $8.57 \%$ respectively, in production of food products, they were $4.27 \%$ and 9.98\%. Armenia and Kyrgyzstan together produce less than $5 \%$ of agricultural products and less than $1 \%$ of foods. These shares are due to both a size of economies, their level of development, and availability of agricultural lands as well as other natural and climatic factors. In this regard, the potential for the development of trade relations related to agricultural products between Russia and Kyrgyzstan/Armenia is more than 10-20 times less than between Russia and Belarus/Kazakhstan, and a focus of further analysis will be on these two countries.

Cooperation of Russia with the CIS countries and the EAEU is limited to the export of innovative products. The food industry exports innovative products mainly to the CIS countries: $98.7 \%$ in $2015,79.1 \%$ in 2016 , while the share of exports of innovative goods to the CIS countries in processing industries was $8.8 \%$ in 2016, the share of exports of innovative products in the whole economy being $9.2 \%$ [17], but it does not export new technologies to either the CIS countries or to foreign countries.

There is a potential for cooperation in the field of innovations in the agri-food sector. After some decline in investment activity in agriculture of Russia and Belarus, in 2017 there was an increase in the volume of investments; an increase in labor productivity is also observed (Table 2 ).

Table 2. Dynamics of labor productivity and investments in fixed assets in agriculture of Russia, Belarus and Kazakhstan (in comparable prices of 2010)

\begin{tabular}{|c|c|c|c|c|c|c|}
\hline Indicator & 2012 & 2013 & 2014 & 2015 & 2016 & 2017 \\
\hline \multicolumn{7}{|c|}{ Russia } \\
\hline Labor productivity, million rubles/person & 0.47 & 0.50 & 0.53 & 0.63 & 0.66 & 0.73 \\
\hline Investments in fixed assets, million rubles & 413.62 & 429.75 & 397.07 & 348.92 & 392.61 & 430.77 \\
\hline \multicolumn{7}{|c|}{ Belarus } \\
\hline Labor productivity, billion Bel. rubles/person & 0.0905 & 0.0918 & 0.0952 & 0.0923 & 0.0966 & 0.1027 \\
\hline Investments in fixed assets, billion Bel. rubles & 8670.97 & $10,733.15$ & $9,240.53$ & $7,973.76$ & $8,111.24$ & $10,320.71$ \\
\hline \multicolumn{7}{|c|}{ Kazakhstan } \\
\hline Labor productivity, million ter & 0.7145 & 0.9639 & 1.1465 & 1.3824 & 1.3861 & 1.4228 \\
\hline Investments in fixed assets, billion tenge & $1,268.57$ & $1,302.70$ & $1,269.79$ & $1,263.70$ & $1,242.98$ & $1,289.29$ \\
\hline
\end{tabular}

Source: [19-21]

Evaluation of the innovation activity of the EAEU countries based on a comparison of specific investments (per one employed in agriculture) and the dynamics of labor productivity for the period from 2012 to 2017 showed an upward trend in the intensity of innovation in agriculture in Russia and Belarus and a downward trend in agriculture in Kazakhstan [22] (Fig. 2).

The peak of the intensity of innovation in Russian agriculture in 2015 is associated with the 
introduction of an embargo on the supply of imported products, a sharp decline in imports and the intensification of Russian agricultural producers. In the period of 2014-2015, less investment was required to increase labor productivity per unit.
However, already in the next year 2016, there was a trend towards a decrease in the intensity of innovation activity against the background of the lack of competition from imports of EU countries [23].

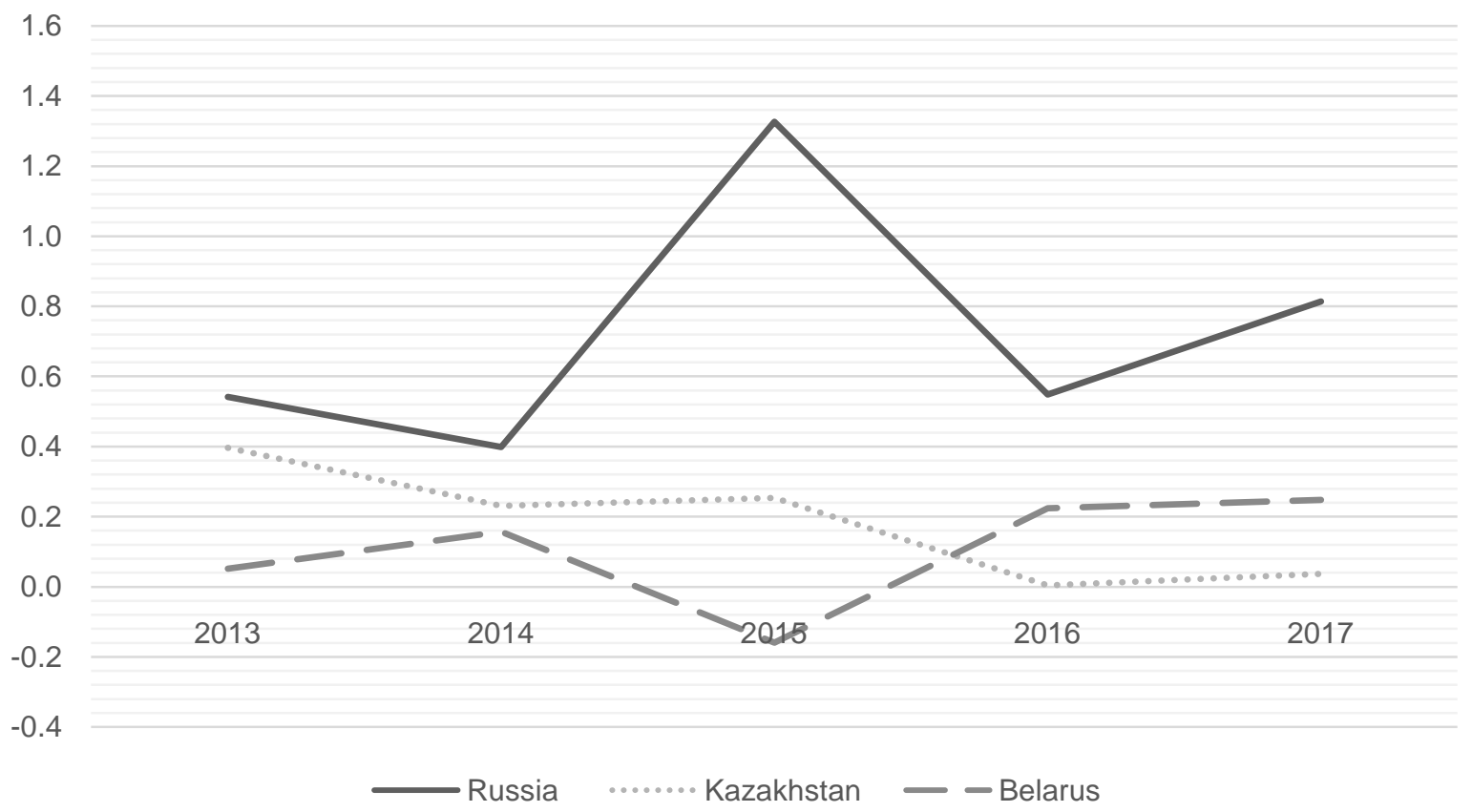

Fig. 2. Indicator of the intensity of innovation activities of Russia, Belarus, and Kazakhstan Source: [19-21]

For a comparative analysis of the current level of countries' readiness for digital transformation and the level of ICT development, a number of indicators can be used. One of these indices is developed by the International Telecommunication
Union. In accordance with this indicator, the EAEU countries do not occupy leading positions in the world ranking on the ICT Development Index (IDI): Belarus ranks $32^{\text {nd }}$, Russia $-45^{\text {th }}$, Kazakhstan $-52^{\text {nd }}$ [24].

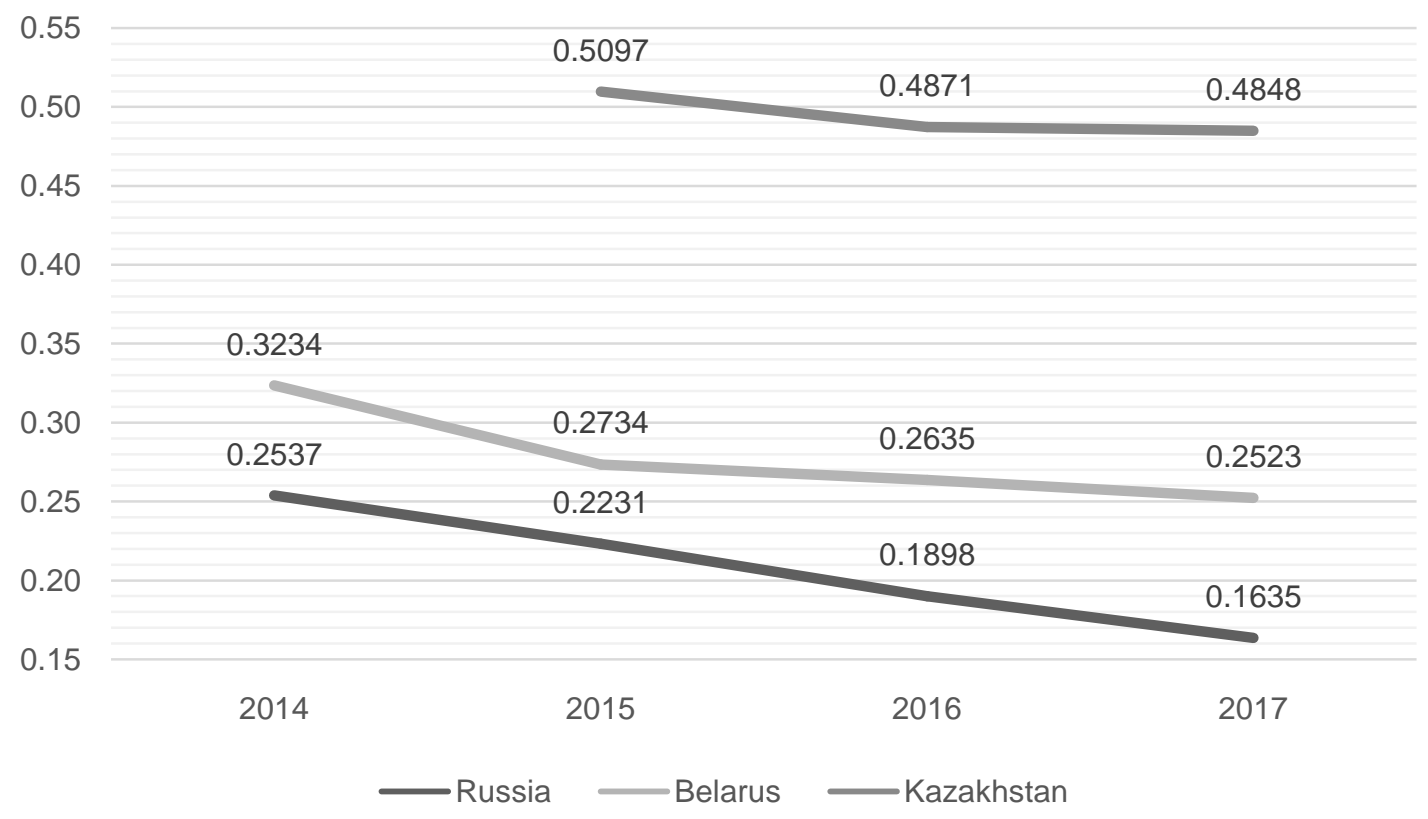

Fig. 3. Indicator of reduction in digital inequality Source: $[25,26,21]$ 
To assess the interaction potential of countries in the field of digitization of the agri-food sector of the EAEU countries, the authors analyzed the main indicators of informatization [27], which showed approximately the same level of digitalization of the EAEU member countries. One of the main conditions for the digitalization of the agroindustrial sector is the reduction of digital inequality between rural and urban areas. An assessment of the reduction of the digital inequality of the rural population in terms of access to the Internet in Belarus, Kazakhstan and Russia shows a cl ear downward trend in all of the countries. Nevertheless, the digital divide is still high, especially in the Republic of Kazakhstan (Fig. 3).

\section{Discussion}

Despite the growing trend of intensification of innovation in agriculture, the level of introduction of advanced technologies in this sector of the economy remains extremely low. The low rate of introduction of digital technologies in the agri-food sector is explained by an unsystematic approach to the process of digital transformation and such problems as:

- lack of a sufficient amount of domestic-made equipment and technologies, in particular, all robotics currently used in agriculture are foreign-made;

- lack of scientifically based recommendations developed for the Russian conditions on the use and introduction of ICT, digital and robotic technologies in the Russian agro-industry;

- insufficient knowledge of the effectiveness of the use of digital technologies in the agri-food sector, which hinders their implementation due to the high cost of equipment and technology;

- insufficient theoretical knowledge of the problem of using digital technologies in agriculture, the feasibility of the introduction and effectiveness of the use of digital technologies in comparison with traditional farming technologies;

- lack of specialists in the agri-food sector and, above all, in agriculture (zoo-engineers, veterinarians, etc.), possessing digital competencies that allow them to master and use digital technologies [6].

A digital transformation of the agri-food sector depends on external and internal factors. The factors of the internal environment that have a direct impact on the possibility and success of digital transformation, in addition to available access to the
Internet and, consequently, to ICT, which, as evidenced by this research, shows a reduction in the backlog of rural areas from urban areas, include a number of other factors. These factors are the efficiency of the labor management system, the applied management technologies, the availability of automated management systems, the level of professionalism and qualifications, etc. Many of these factors not only affect the possibility of digitization of agriculture but also directly determine it [4].

In the agri-food sector of Russia, as in other countries, the problem of effective interaction and cooperation between business and organizations engaged in scientific research and development is extremely acute. The focus on the acquisition of predominantly embodied technologies and the weak interest of domestic enterprises in the real sector of the economy to innovation activity has been noted in many studies (e.g., [14]).

The lack of involvement of agri-food enterprises in cooperation ties in the field of innovations is caused, as some researchers believe, by the lack of sufficient awareness of agricultural and food producers on the production capabilities of equipment manufacturers and technology developers from EAEU partner countries. This problem can be solved by digitization of the agrifood sector, which entails the development of new forms of cooperation that promote the incorporation of enterprises and organizations of the agri-food sector into the value chains, increase competition in the market of the EAEU countries, including reducing barriers to mutual trade and reducing costs on partner search, promoting innovation and productivity growth [3].

Union states have taken active measures to promote digitalization in economy [28-29]. In 2017, Russia had the Digital Economy program aimed at the integrated and systematic development and introduction of digital technology in all spheres of the life. In 2017, Kazakhstan approved the corresponding state program of five key areas: digitalization in sectors of economy, transition to the digital government, implementation of the digital Silk Road; human capital development, creation of the innovative ecosystem. In 2017, Belarus adopted Decree "On the Development of Digital Economy". In parallel with the decree, there is the state program for the development of digital economy and information society. 


\section{Conclusion}

The study showed the presence of an increasing trend in the intensity of innovation activity in the agri-food sector of three largest economies in the EAEU due to the Russian import substitution policy. The ban on the supply of food products from several EU countries and the reduction of their imports contributed to the revitalization of domestic agricultural producers. However, despite the achievement of certain successes in the development of agriculture, in the field of digital technologies, Russian agriculture still lags behind other sectors of the economy, aggravated by the trend towards a decrease in the intensity of innovation activity against the background of a lack of competition from imports from the EU countries.

The study revealed the potential for the development of cooperation in the agri-food sector. At present, cooperation ties of the EAEU countries are developing mainly in the trade sphere. The greatest potential is in trade relations between Russia, Belarus and Kazakhstan. As for Belarus, it is mainly in trade $(10.3 \%)$, as for Kazakhstan, it is both in trade $(5.1 \%)$ and the production sphere $(5.89 \%)$. Russia's cooperation with the countries of the EAEU is limited to the export of innovative products. The food industry exports innovative products mainly to the CIS countries: $98.7 \%$ in $2015,79.1 \%$ in 2016 , while the share of exports of innovative goods to the CIS countries in processing industries was $8.8 \%$ in 2016, while the share of exports of innovative products in the economy as a whole is $9.2 \%$, but it does not export new technologies either to the CIS countries or to foreign countries. The results of the development analysis for a number of countries support such trends towards the changed export [30-32].

\section{References:}

[1] Romanova, O.A., Korovin, G.B., Kuzmin, E.A., Analysis he Development Prospects for the High-Tech Sector of the Economy in the Context of New Industrialization, Espacios, Vol. 38, No. 59, 2017, p. 25.

[2] Platonova, T.E., Problems of Using International Experience in the Innovation Development of the Agricultural Sector of Russia, Russia: Trends and Development Prospects, Vol. 13, No. 1. 2018, pp. 339-342.

[3] Karlik, A.E., Krechko, S.A., Platonov, V.V., Industrial Cooperation of the EAEU Member Countries in the Perspective of the Digital Economy, MID (Modernization. Innovations. Development), Vol. 3, No. 31, 2017, pp. 384 -
395.

https://doi.org/10.18184/2079-

4665.2017.8.3.384-395

[4] Lazko, O.V., Semchenkova, S.V., Lukasheva, O.L., Strategic Guidelines for the Management of Digital Transformation Processes in the Agro-Industrial Sector, Moscow Economic Journal, No. 4, pp. $507 \quad-518$. doi:10.24411/2413-046X-2018-14042

[5] Radwan, A., Science and Innovation Policies in North African Countries: Exploring Challenges and Opportunities, Entrepreneurship and Sustainability Issues, Vol. 6, No. 1, 2018, pp . 268-282.

https://doi.org/10.9770/jesi.2018.6.1(17)

[6] Skvortsov, E.A., Skvortsova, E.G., Sandu, I.S., Iovlev, G.A., The Transition of Agriculture to Digital, Intellectual and Robotic Technologies, Economy of the Region, No. 3, 2018, pp. 10141028. https://doi.org/10.17059/2018-3-23

[7] Harold, E.M., Woodard, J., Glos, M., Verteramo, L., Digital Agriculture in New York State: Report and Recommendations, Ithaca, N.Y.: Cornell University, 2016.

[8] TongKe, F., Smart Agriculture Based on Cloud Computing and IOT, Journal of Convergence Information Technology, Vol. 8, No. 2, 2017, pp. 210-216.

https://doi.org/10.4156/jcit.vol8.issue2.26

[9] Lavrovsky, B.R., Murzov, I.A., Luzin, R.S., Innovations as a Factor of European Economic Dynamics (Empirical Analysis), Spatial Economics, No. 2, 2 015, pp. 86 -102. https://doi.org/10.14530/se.2015.2.086-102

[10] Spasskaya, N.V., Kireev, V.E., Investment Aspects of Increasing Labor Productivity in the Regions of Russia, Regional Economy: Theory and Practice, Vol. 39, No. 414, 2015, pp. 1729.

[11] Baev, I.A., Solovyova, I.A., Empirical Analysis of the Relationship of Investment and Innovation Activity of the Regions of Russia, Economy of the Region, No. 1, 2014, pp. 147 155. https://doi.org/10.17059/2014-1-13

[12] Fomina, A.V., Berduygina, O.N., Shatsky, A.A., Industrial Cooperation and Its Influence on Sustainable Economic Growth, Entrepreneurship and Sustainability Issues, Vol. 5, N o. 3, 2018, $467 \quad-479$. https://doi.org/10.9770/jesi.2018.5.3(4)

[13] Shumov, A.V., International Cooperation in the Market of Food Equipment, Russian Foreign Economic Journal, No. 10, 2013, pp. 110-115.

[14] Zaichenko, S., Kuznetsova, T., Roud, V., Features of Interaction Between Russian Enterprises and Research Organisations in the 
Field of Innovation, Foresight-Russia, Vol. 8, No. $1,20 \quad 14, \quad$ pp. $6 \quad-23$. https://doi.org/10.17323/1995459x.2014.1.06.23

[15] Kovács, I., Husti, I., The Role of Digitalization in the Agricultural 4.0 - How to Connect the Industry $4.0 \mathrm{t}$ o Agriculture? Hungarian Agricultural Engineering, No.33, 2018, pp. 3842. https://doi.org/10.17676/HAE.2018.33.38

[16] Kurunina, E.N., Study of the Level of Cooperation in the Innovation Sphere, National Interests: Priorities and Security, No. 2, 2014, pp. 55-60.

[17] Gorodnikova, N.V., Gokhberg, L.M., Ditkovsky, K.A. et al., Indicators of Innovation Activity (2018): Statistical Compilation, Moscow: National Research University "Higher School of Economics", 2018.

[18] Interstate Statistical Committee of the Commonwealth of Independent States (2020). http://www.cisstat.com/

[19] Rosstat, $\quad$ Database, 2019. http://www.gks.ru/wps/wcm/connect/rosstat m ain/rosstat/ru/statistics/enterprise/economy/

[20] Belstat, National Statistics Committee of Belarus, Economic Statistics, 2018. http://www.belstat.gov.by/ofitsialnayastatistika/realny-sector-ekonomiki//

[21] Committee for Statistics of Kazakhstan, 2019. http://stat.gov.kz/faces/wcnav_externalId/publi cationsPage? afrLoop $=8294974546892809 \# \%$ 40\%3F afrLoop\%3D8294974546892809\%26 adf.ctrl-state \%3Dqzoc35vlm 21

[22] Yerseitova, A., Issakova, S., Jakisheva, L., Nauryzbekova, A., Moldasheva, A., Efficiency of Using Agricultural Land in Kazakhstan, Entrepreneurship and Sustainability Issues, Vol. 6, No. 2, 2018 pp. 558-576. https://doi.org/10.9770/jesi.2018.6.2(7)

[23] Krylatykh, E.N., Belova, T.N., Russian Grain Exports in the Context of the Formation of Regional Economic Policy, Economy of the Region, No. 3, 2018, pp. 778-790. https://doi.org/10.17059/2018-3-7

[24] ITU, Measuring the Information Society Report, 2017. https://www.itu.int/en/ITU-
D/Statistics/Documents/publications/misr2017/ MISR2017_Volume1.pdf

[25] Sabelnikova, M.A., Abdrakhmanova, G.I., Gokhberg, L.M., Dudorova, O.Yu. et al., Information Society in the Russian Federation. 2018: Statistics Bulletin, Moscow: Rosstat; National Research University "Higher School of Economics", 2018.

[26] National Statistics Committee of Belarus, Information Society in the Republic of Belarus. Statistics Bulletin, 2017.

[27] Veselovsky, M.Y., Pogodina, T.V., Ilyukhina, R.V., Sigunova, T.A., Kuzovleva, N.F., Financial and Economic Mechanisms of Promoting Innovative Activity in the Context of the Digital Economy Formation, Entrepreneurship and Sustainability Issues, Vol. 5, No. 3, 2018, pp. 672-681. https://doi.org/10.9770/jesi.2018.5.3(19)

[28] Blatova, T. A., Makarov, V. V., ShuvalSergeeva, N. S. Quantitative and qualitative aspects of measuring the digital economy, Radio industry (Russia), Vol. 29, No. 4, 2019, pp. 63-72. https://doi.org/10.21778/2413-95992019-29-4-63-72

[29] Batkovsky, A. M., Kalachykhin, P. A., Telnov, Yu. F., Fomina, A.V. Assessment of the level of requirements to key competences of enterprises in the conditions of the digital economy, Radio industry (Russia), Vol. 29, No. 3, 2019, 2 pp. $91 \quad-99$. https://doi.org/10.21778/2413-9599-2019-29-391-99

[30] Vdovychenko, A., Zubrytskyi, A. Effects of Fiscal Consolidation on Exports in Ukraine, Journal of Eurasian Economic Dialogue, Vol. 1, No. 3, 2016, pp. 1-13.

[31] Javed, Z., Munir, K. Impact of Export Composition on E conomic Growth in South Asia, Journal of Eurasian Economic Dialogue, Vol. 1, No. 3, 2016, pp. 28-42.

[32] Molina, J. A., Velilla, J., Ortega, R. Entrepreneurial Activity in the OECD: Pooled and Cross-Country Evidence, Journal of Eurasian Economic Dialogue, Vol. 1, N o. 6, 2016, pp. 1-18. 